\title{
Response of the jejunal mucosa of dogs with aerobic and anaerobic bacterial overgrowth to antibiotic therapy
}

\author{
ROGER M BATT, LYNN MCLEAN, AND JANE E RILEY \\ From the Department of Veterinary Pathology, University of Liverpool, Liverpool
}

SUMMARY Dogs with naturally occurring aerobic or anaerobic bacterial overgrowth have been examined before and after antibiotic therapy in order to assess reversibility of damage to the jejunal mucosa. Histological changes in peroral jejunal biopsies were relatively minor before and after treatment, but sucrose density gradient centrifugation revealed specific biochemical abnormalities that responded to antibiotic therapy. Aerobic overgrowth was initially associated with a marked loss of the main brush border component of alkaline phosphatase activity; this recovered following treatment, suggesting that aerobic bacteria may cause reversible damage to the hydrophobic region of the brush border membrane. In contrast, anaerobic overgrowth was initially associated with a marked reduction in brush border density, indicative of a considerable fall in the glycoprotein-tolipid ratio of the membrane. Density increased from 1.17 to $1.21 \mathrm{~g} / \mathrm{ml}$ after antibiotic therapy, consistent with recovery from this relatively severe damage to the brush border caused by anaerobic bacteria. Reductions in soluble and peroxisomal catalase activities which could compromise mucosal protection against free radicals in dogs with aerobic overgrowth, and a loss of particulate malate dehydrogenase activity indicative of mitochondrial disruption in dogs with anaerobic overgrowth, were also reversed after treatment. These findings indicate that aerobic and anaerobic bacterial overgrowth can result in contrasting but potentially reversible damage to the jejunal mucosa which would not be detected by conventional investigative procedures.

In the blind loop syndrome in $\operatorname{man}^{1-4}$ and in experimental animals ${ }^{2.3513}$ an association has been established between chronic overgrowth of predominantly obligate anaerobic bacteria and functional damage to enterocytes. In addition, it has been suggested that longterm colonisation, particularly with coliform bacteria, might play a role in the pathogenesis of the relatively severe morphological damage to the small intestine in chronic tropical sprue in man..$^{1416}$ While the potential longterm consequences of an abnormal flora on the mucosa of the small intestine have been studied extensively, the possibility that there may be irreversible components to these mucosal abnormalities ${ }^{2361415}$ has received relatively little attention.

A naturally occurring disease in the dog associated with bacterial overgrowth in the proximal small

Address for correspondence: $\operatorname{Dr}$ R M Batt, Department of Veterinary Pathology, University of Liverpool, PO Box 147, Liverpool L69 3BX, UK.

Received for publication 23 October 1987. intestine has provided the opportunity to explore relationships between an abnormal flora and mucosal damage. ${ }^{178} \mathrm{~A}$ comparison between dogs with aerobic and anaerobic overgrowth has revealed differences in biochemical abnormalities which indicate that the composition of the overgrowth flora can have an important influence on the nature of mucosal damage. ${ }^{18}$ The present study examines the effects of antibiotic treatment on these mucosal changes in order to determine whether damage is reversible, and hence a direct consequence of the overgrowth.

\section{Methods}

A N I M A LS

Affected animals with aerobic or anaerobic overgrowth of bacteria comprised eight German shepherd dogs aged between five months and three years (median 14 months) referred for an investigation of chronic diarrhoea of at least three months 
Table 1 Serum folate, serum cobalamin and total viable bacteria in the duodenal juice of dogs with either aerobic or anaerobic bacterial overgrowth before and after antibiotic treatment.

\begin{tabular}{|c|c|c|c|c|c|c|c|}
\hline \multirow[b]{2}{*}{$\begin{array}{l}\text { Case } \\
\text { no }\end{array}$} & \multirow[b]{2}{*}{$\begin{array}{l}\text { Initial } \\
\text { overgrowth }\end{array}$} & \multicolumn{3}{|c|}{ Pretreatment } & \multicolumn{3}{|c|}{ Post-treatment } \\
\hline & & $\begin{array}{l}\text { Folate } \\
(\mu g / l)\end{array}$ & $\begin{array}{l}\text { Cobalamin } \\
\text { (ng/l) }\end{array}$ & $\begin{array}{l}\text { Bacteria } \\
\left(\log _{10} / m l\right)\end{array}$ & $\begin{array}{l}\text { Folate } \\
(\mu g / l)\end{array}$ & $\begin{array}{l}\text { Cobalamin } \\
(n g / l)\end{array}$ & $\begin{array}{l}\text { Bacteria } \\
\left(\log _{10} / \mathrm{ml}\right)\end{array}$ \\
\hline 1 & Aerobic & $8 \cdot 4$ & 40 & 6.9 & $7 \cdot 6$ & 85 & $4 \cdot 2$ \\
\hline 2 & Aerobic & $6 \cdot 6$ & 125 & $6 \cdot 4$ & $5 \cdot 5$ & 85 & $7 \cdot 2$ \\
\hline 3 & Aerobic & $17 \cdot 1$ & 80 & $6 \cdot 2$ & $18 \cdot 5$ & 150 & $5 \cdot 5$ \\
\hline 4 & Aerobic & $18 \cdot 5$ & 83 & $5 \cdot 7$ & $20 \cdot 9$ & 146 & $<3.0$ \\
\hline 5 & Anaerobic & 54 & 130 & $7 \cdot 6$ & $36 \cdot 7$ & 330 & ND \\
\hline 6 & Anaerobic & $17 \cdot 4$ & 176 & $7 \cdot 2$ & $20 \cdot 3$ & 110 & 6.9 \\
\hline 7 & Anaerobic & $18 \cdot 9$ & 170 & $6 \cdot 0$ & 7.9 & 185 & 5.9 \\
\hline 8 & Anaerobic & $10 \cdot 3$ & 242 & $5 \cdot 6$ & $9 \cdot 3$ & 315 & 4.9 \\
\hline \multicolumn{2}{|c|}{ Control range ${ }^{*}$} & $4 \cdot 8-13 \cdot 0$ & $200-400$ & $<4 \cdot 3$ aerobes & & & \\
\hline
\end{tabular}

ND not determined. ${ }^{*}$ References 20 and 22.

Table 2 Details of the bacterial flora in dogs with aerobic or anaerobic overgrowth before and after antibiotic treatment

\begin{tabular}{|c|c|c|c|}
\hline \multirow{2}{*}{$\begin{array}{l}\text { Case } \\
\text { no }\end{array}$} & \multirow{2}{*}{$\begin{array}{l}\text { Initial } \\
\text { overgrowth }\end{array}$} & \multicolumn{2}{|l|}{ Viable bacteria in duodenal juice $\left(\log _{10} / \mathrm{ml}\right)$} \\
\hline & & Pretreatment & Post-treatment \\
\hline 1 & Aerobic & $\begin{array}{l}\text { 6.5 (Ac 1), } 6 \cdot 4(\mathrm{E}), 6 \cdot 1(\mathrm{M} \mathrm{spp}), 5 \cdot 9(\mathrm{Ec}), 5 \cdot 6(\text { Pas spp) } \\
5 \cdot 4(\mathrm{St} \mathrm{spp})\end{array}$ & 3.7 (Ps spp), 3.6(E), 3.5 (M sp), 3.3(Pas sp), 3.0(Ec) \\
\hline 2 & Aerobic & $6 \cdot 4(\mathrm{Aca})$ & $6 \cdot 9$ (Pas spp), $6 \cdot 7(\mathrm{~N} \mathrm{spp}), 6 \cdot 4$ (Ps sp), $5 \cdot 8(\mathrm{Ac} \mathrm{a}), 5 \cdot 7(\mathrm{Lc} \mathrm{sp})$ \\
\hline 3 & Aerobic & $\begin{array}{l}5.9 \text { (Ac 1), } 5 \cdot 4 \text { (Ps spp), } 5 \cdot 3(\mathrm{E}), 5 \cdot 2 \text { (Pas spp), } 3 \cdot 7(\mathrm{Ec}) \text {, } \\
3.4 \text { (St spp) }\end{array}$ & $\begin{array}{l}5 \cdot 5 \text { (Ac } 1), 4 \cdot 5 \text { (St spp), 3.8 (E), 3.7 (Ec), 3.2 (Bb), } \\
3 \cdot 2 \text { (Ps spp) }\end{array}$ \\
\hline 4 & Aerobic & $5 \cdot 6(\mathrm{Ste}), 4 \cdot 6(\mathrm{St} a)$ & $<3 \cdot 0$ \\
\hline 5 & Anaerobic & $>7.5(\mathrm{Cl} \mathrm{sp})^{*},>6 \cdot 6(\mathrm{Bf} \mathrm{sp})^{*}, 6 \cdot 5(\mathrm{Ec}), 5 \cdot 7(\mathrm{E})$ & ND \\
\hline 6 & Anaerobic & $7 \cdot 1(\mathrm{Lc} \mathrm{spp}), 6 \cdot 51(\mathrm{Cor} \mathrm{sp})^{*}, 6 \cdot 15(\mathrm{Cl} \mathrm{spp})^{*}, 4 \cdot 9$ (St spp) & $6 \cdot 6(\mathrm{E}), 6 \cdot 5(\mathrm{M} \mathrm{sp}), 6 \cdot 0(\mathrm{Cor} \mathrm{sp}), 5 \cdot 8(\mathrm{Ec}), 5 \cdot 4(\mathrm{Lcsp})$ \\
\hline 7 & Anaerobic & $5 \cdot 8(\mathrm{Bac} \mathrm{sp})^{*}, 5 \cdot 49(\mathrm{~Sv}), 4 \cdot 7(\mathrm{Bs}), 3 \cdot 8(\mathrm{Ec}), 3 \cdot 0(\mathrm{Cl} \mathrm{w})^{*}$ & $5 \cdot 5(\mathrm{Bac} \mathrm{sp})^{*}, 5 \cdot 4$ (Pas sp), $5 \cdot 3$ (Ps sp), $5 \cdot 1$ (N spp), $4 \cdot 0$ (Ec) \\
\hline 8 & Anaerobic & $5 \cdot 54(\mathrm{Cl} \mathrm{w})^{*}, 3 \cdot 4(\mathrm{Ec})$ & $4 \cdot 9$ (Sf), $4 \cdot 3$ (St sp) \\
\hline
\end{tabular}

Ac a, Acinetobacter calcoaceticus var anitratus; Ac 1, Acinetobacter calcoaceticus var lwoff; Bac sp, Bacteroides sp; Bb, Bordetella bronchiseptica; $\mathrm{Bf} \mathrm{sp}$, Bifidobacterium $\mathrm{sp} ; \mathrm{Bs}$, Bacillus subtilis; $\mathrm{Cl} \mathrm{sp}(\mathrm{p})$, Clostridium $\mathrm{sp}(\mathrm{p}) ; \mathrm{Cl} \mathrm{w}$, Clostridium welchii; Cor $\mathrm{sp}$,

Corynebacterium sp; E, Enterococcus; Ec, Escherichia coli; Lc sp(p), Lactobacillus sp(p); M sp(p), Moraxella sp(p), N sp(p), Neisseria sp(p); Pas sp(p), Pasteurella sp(p); Ps sp(p) Pseudomonas sp(p); Sf, Streptococcus faecalis; St a, Staphylococcus aureus; St e, Staphylococcus epidermidis; $\mathrm{St} \mathrm{sp}(\mathrm{p})$ Staphylococcus $\mathrm{sp}(\mathrm{p}) ; \mathrm{Sv}$, Streptococcus viridans.

${ }^{*}$ obligate anaerobes. ND not determined.

duration, accompanied in seven cases by loss of weight. Sequential numbers in Tables 1 and 2 represent cases 4, 7, 8, 9 (aerobic overgrowth) and cases $11,12,15,17$ (anaerobic overgrowth) for which data before treatment have been presented previously. ${ }^{18}$ Investigations were repeated between two to six days after completion of treatment with oral oxytetracycline (10-20 mg/kg every eight hours for 28 days). This treatment resulted in considerable improvement in the incidence and severity of diarrhoea in all cases, and weight gain in four of the seven underweight animals.

Control animals were clinically healthy dogs of various pure breeds, including nine German shepherd dogs, aged between six months and 10 years (median two years) with no functional or histological evidence of jejunal abnormality. Data were initially evaluated by Levene's test for homogeneity of variance. Significance of differences between control and affected groups before and after treatment was then determined either by one-way analysis of variance and Dunnett's test, or by the Kruskal-Wallis test. Comparisons within affected groups before and after treatment were undertaken by use of Student's $t$ test for paired data or, where indicated, by Wilcoxon's signed-rank test.

\section{CLINICAL INVESTIGATIONS}

Details of the procedures for the clinical investigation of affected animals, including the assay of serum folate and cobalamin, have been presented previously with relevant control data. ${ }^{19} 20$ All animals had normal exocrine pancreatic function, assessed by the assay of serum trypsin like immunoreactivity ${ }^{21}$ and in seven dogs by the oral administration of N-benzoylL-tyrosyl-p-aminobenzoic acid (bentiromide). ${ }^{19}$ 
Routine examinations of faeces and duodenal juice revealed no evidence of intestinal parasites apart from ova of Toxocara $\mathrm{sp}$ in faeces of case 5. This animal was included because no specific effects of this infection on the jejunal mucosa were discernible and biopsy findings were comparable with those in the other animals in this anaerobic group. ${ }^{18}$

Bacterial overgrowth was documented by quantitative and qualitative bacteriological investigations of duodenal juice obtained by peroral intubation after fasting for approximately 18 hours. ${ }^{22}$ Jejunal biopsy specimens for morphological and biochemical investigations were obtained perorally from a site just distal to the duodenal-jejunal flexure, using a single or multiple biopsy capsule..$^{23}$

\section{BIOCHEMICAL STUDIES}

Portions of jejunal biopsy specimens (approximately $10-50 \mathrm{mg}$ ) were homogenised in sucrose medium $(0.3 \mathrm{~mol} / \mathrm{l}$ sucrose, $22 \mathrm{mmol} / \mathrm{l}$ ethanol, $1 \mathrm{mmol} / \mathrm{l}$ $\mathrm{Na}_{2}$ EDTA, $\mathrm{pH} 7 \cdot 4$ ) and postnuclear supernatant fractions were subjected to analytical subcellular fractionation by sucrose density gradient centrifugation either in an automatic zonal rotor $^{24}$ or vertical tube rotor. ${ }^{25}$ After centrifugation, alkaline phosphatase was assayed immediately and then the gradient fractions were stored at $-20^{\circ} \mathrm{C}$ before further assay. Results are expressed in the form of frequencydensity histograms, the averaging of distributions being done by computer. ${ }^{26}$ Marker enzymes for the principal subcellular organelles were assayed in the homogenates and gradient fractions as described previously. ${ }^{24} 27$ Maltase, sucrase, and lactase were assayed in portions of biopsy specimens collected in distilled water. ${ }^{28}$ Protein was assayed ${ }^{29}$ with bovine serum albumin (Armour Pharmaceutical Co, Chicago, USA) as standard.

\section{Results}

\section{CLINICAL INVESTIGATIONS}

Table 1 shows that before treatment serum folate concentrations were raised in five cases, and serum cobalamin concentrations were reduced in seven cases, findings consistent with synthesis of folate and binding of intraluminal cobalamin by enteric bacteria. After antibiotic therapy, serum folate concentrations decreased in five dogs while cobalamin concentrations increased in six dogs.

Tables 1 and 2 show that total viable bacterial counts in duodenal juice before treatment were greater than $10^{5}$ organisms $/ \mathrm{ml}$ in all affected dogs, comprising exclusively aerobic bacteria in four cases and predominantly obligate anaerobic bacteria, particularly Clostridia spp, in the other four cases. The most notable changes after treatment included a reduction in total viable counts in three of the four animals that had aerobic overgrowth, and a loss particularly of Clostridia spp in the duodenal samples taken from the dogs that had anaerobic overgrowth before treatment.

Dissection and light microscopy of peroral jejunal biopsy specimens revealed minimal morphological damage, which included partial villous atrophy in specimens from cases 1,2 , and 7 , and prominent lymphocyte/plasma cell infiltrates in the lamina propria of specimens from cases 1,7 , and 8 . Treatment resulted in some improvement in the morpho-

Table 3 Activities of brush border marker enzymes in jejunal biopsy specimens from controls and dogs with aerobic or anaerobic overgrowth before and after antibiotic treatment

\begin{tabular}{|c|c|c|c|c|c|c|}
\hline \multirow{2}{*}{$\begin{array}{l}\text { Enzyme } \\
\text { (ECno) }\end{array}$} & \multirow[b]{2}{*}{ Control } & \multicolumn{2}{|l|}{ Aerobic overgrowth } & \multicolumn{3}{|c|}{ Anaerobic overgrowth } \\
\hline & & Pre-treatment & Post-treatment & Pre-treatment & & Post-treatment \\
\hline $\begin{array}{l}\text { Zn-resistant } \alpha \text {-glucosidase } \\
(3.2 .1 .20)\end{array}$ & $\begin{array}{c}6 \cdot 2(0 \cdot 2) \\
{[23]}\end{array}$ & $6 \cdot 8(1 \cdot 0)[\mathrm{NS}]{ }_{[\mathrm{NS}]}$ & $7 \cdot 1(0 \cdot 7)[N S]$ & $6 \cdot 5(1 \cdot 2)(\mathrm{NS})$ & [NS] & $6 \cdot 7(0 \cdot 8)[N S]$ \\
\hline $\begin{array}{l}\text { Maltase } \\
(3.2 .1 .20)\end{array}$ & $\begin{array}{c}347(19) \\
{[18]}\end{array}$ & $368(75)[N S]$ & 405 (46) [NS] & $309(41)[N S]$ & [NS] & $361(50)[N S]$ \\
\hline $\begin{array}{l}\text { Sucrase } \\
(3.2 .1 .48)\end{array}$ & $\begin{array}{c}77 \cdot 5(5 \cdot 5) \\
{[18]}\end{array}$ & $99 \cdot 5(13)[N S]$ & $94 \cdot 5(26)[N S]$ & $68 \cdot 7(13)[\mathrm{NS}]$ & [NS] & $84 \cdot 2(11)$ [NS] \\
\hline $\begin{array}{l}\text { Lactase } \\
(3.2 .1 .23)\end{array}$ & $\begin{array}{c}31 \cdot 3(3 \cdot 2) \\
{[17]}\end{array}$ & $26 \cdot 2[4 \cdot 4][\mathrm{NS}]{ }_{[\mathrm{NS}]}^{[1.5]}$ & $21 \cdot 9(3 \cdot 3)[\mathrm{NS}]$ & $26 \cdot 6(6 \cdot 2)[N S]$ & [NS] & $27 \cdot 4(1 \cdot 9)[\mathrm{NS}]$ \\
\hline $\begin{array}{l}\text { Alkaline phosphatase } \\
(3.1 .3 .1)\end{array}$ & $\begin{array}{c}125(11) \\
{[21]}\end{array}$ & $69 \cdot 5(21)[<0 \cdot 05]$ & $98 \cdot 4$ (29) [NS] & $73 \cdot 1(6 \cdot 7)[<0.05]$ & & $85 \cdot 2(6 \cdot 3)[\mathrm{NS}]$ \\
\hline $\begin{array}{l}\text { Aminopeptidase } \mathrm{N} \\
(3.4 .11 .1)\end{array}$ & $\begin{array}{c}95 \cdot 1(6 \cdot 7) \\
{[22]}\end{array}$ & $77 \cdot 2(9 \cdot 0)[\mathrm{NS}]{ }_{[\mathrm{NS}]}$ & $77 \cdot 1(7 \cdot 9)[\mathrm{NS}]$ & $84 \cdot 7(22)[\mathrm{NS}]$ & [NS] & $132(34)[N S]$ \\
\hline $\begin{array}{l}\gamma \text {-Glutamyl transferase } \\
(2.3 .2 .2)\end{array}$ & $\begin{array}{c}11 \cdot 1(0 \cdot 4) \\
{[21]}\end{array}$ & $\begin{array}{r}11 \cdot 7(1 \cdot 8)[\mathrm{NS}] \\
{[\mathrm{NS}]}\end{array}$ & $10 \cdot 0(1.4)[\mathrm{NS}]$ & $11 \cdot 8(4 \cdot 2)[\mathrm{NS}]$ & [NS] & $14 \cdot 4(2 \cdot 1)[\mathrm{NS}]$ \\
\hline
\end{tabular}

Data (mU/mg protein) are expressed as mean (SE). Numbers between square brackets indicate number of control animals and statistical differences between control and affected groups [to the side] and within affected groups $(n=4)$ before and after treatment [below]. [NS] $=$ not significant $(p>0 \cdot 05)$. 
Table 4 Activities of organelle marker enzymes in jejunal biopsy specimens from controls and dogs with aerobic or anaerobic overgrowth before and after antibiotic treatment

\begin{tabular}{|c|c|c|c|c|c|c|c|}
\hline \multirow{2}{*}{$\begin{array}{l}\text { Enzyme } \\
\text { (ECno) }\end{array}$} & \multirow[b]{2}{*}{ Control } & \multicolumn{3}{|l|}{ Aerobic overgrowth } & \multicolumn{3}{|c|}{ Anaerobic overgrowth } \\
\hline & & Pre-treatment & & Post-treatment & Pre-treatment & & Post-treatment \\
\hline $\begin{array}{l}5^{\prime} \text {-Nucleotidase } \\
(3.1 .3 .5)\end{array}$ & $\begin{array}{c}2 \cdot 7(0 \cdot 22) \\
{[17]}\end{array}$ & $3 \cdot 6(0 \cdot 67)[\mathrm{NS}]$ & [NS] & $5 \cdot 1(1 \cdot 6)[\mathrm{NS}]$ & $1 \cdot 8(0 \cdot 3)[N S]$ & [NS] & $2.9(0.5)[N S]$ \\
\hline $\begin{array}{l}\text { N-Acetyl- } \beta \text {-glucosaminidasc } \\
(3.2 .1 .30)\end{array}$ & $\begin{array}{c}4 \cdot 0(0 \cdot 3) \\
{[22]}\end{array}$ & $5 \cdot 2(0 \cdot 4)[\mathrm{NS}]$ & [NS] & $5 \cdot 8(0 \cdot 4)[p<0 \cdot 05]$ & $3 \cdot 4(0 \cdot 4)[\mathrm{NS}]$ & [NS] & $4 \cdot 1(0 \cdot 3)[\mathrm{NS}]$ \\
\hline $\begin{array}{l}\text { Acid phosphatase } \\
(3.1 .3 .2)\end{array}$ & $\begin{array}{c}5 \cdot 3(0 \cdot 6) \\
{[18]}\end{array}$ & $7 \cdot 0(0 \cdot 7)[\mathrm{NS}]$ & [NS] & $8 \cdot 8(1.5)[p<0 \cdot 05]$ & $4 \cdot 7(0 \cdot 6)[N S]$ & [NS] & $4 \cdot 8(0 \cdot 9)[\mathrm{NS}]$ \\
\hline $\begin{array}{l}\text { Malate dehydrogenase } \\
(1.1 .1 .37)\end{array}$ & $\begin{array}{c}2450(160) \\
{[17]}\end{array}$ & $2640(41)[N S]$ & [NS] & $2300(330)[\mathrm{NS}]$ & $2100(250)[\mathrm{NS}]$ & [NS] & $2180(360)[N S$ \\
\hline $\begin{array}{l}\text { Tris-resistant } \alpha \text {-glucosidase } \\
(3.2 .1 .20)\end{array}$ & $\begin{array}{c}0 \cdot 7(0 \cdot 04) \\
{[22]}\end{array}$ & $1 \cdot 3(0 \cdot 2)[p<0 \cdot 01]$ & [NS] & $1.4(0 \cdot 2)[\mathrm{p}<0.01]$ & $0 \cdot 65(0 \cdot 1)[N S]$ & [NS] & $0.9(0 \cdot 1)[\mathrm{NS}]$ \\
\hline $\begin{array}{l}\text { Catalase } \\
(1.11 .1 .6)\end{array}$ & $\begin{array}{c}8 \cdot 0(0 \cdot 6) \\
{[22]}\end{array}$ & $3.23(0.4)[p<0.01]$ & [NS] & $6 \cdot 3(1 \cdot 6)[N S]$ & $7 \cdot 0(1 \cdot 8)[\mathrm{NS}]$ & [NS] & $9 \cdot 1(1 \cdot 9)[\mathrm{NS}]$ \\
\hline
\end{tabular}

Data (mU/mg protein) are expressed as mean (SE). Numbers between square brackets indicate number of control animals and statistical differences between control and affected groups [to the side] and within affected groups $(n=4)$ before and after treatment (below). [NS] =not significant $(\mathrm{p}>0 \cdot 05)$.

logical appearance of biopsy specimens from cases 1 and 2: in the former, there was a marked reduction in the considerable cellular infiltration of the epithelium and lamina propria observed before antibiotic therapy. The morphological appearance of biopsy specimens from the other dogs was essentially unaltered after treatment.

\section{ENZYME ACTIVITIES}

The specific activities of brush border enzymes in jejunal biopsy specimens from control and affected dogs before and after antibiotic therapy are shown in Table 3. Activity of alkaline phosphatase was initially reduced in both affected groups, and increased following treatment in seven of the eight affected dogs ( $p<0 \cdot 05$, Wilcoxon's signed-rank test) to mean values which were not significantly different in either group from that of the controls. In contrast, specific activities of disaccharidases, aminopeptidase $\mathrm{N}$ and $\gamma$-glutamyl transferase were not significantly affected by antibiotic therapy, and were comparable in the control and affected groups both before and after treatment.

Table 4 shows that treatment had relatively little effect on the specific activities of marker enzymes for basolateral membranes ( $5^{\prime}$-nucleotidase), lysosomes (N-acetyl- $\beta$-glucosaminidase, acid phosphatase), mitochondria (malate dehydrogenase), or endoplasmic reticulum (Tris-resistant $\alpha$-glucosidase) in jejunal biopsy specimens from affected animals with either aerobic or anaerobic overgrowth. Mean specific activities of lysosomal and endoplasmic reticular enzymes were higher in the dogs with aerobic overgrowth than in the controls before and after treatment, although for the lysosomal enzymes these differences before treatment did not reach statistical significance. In contrast, mean catalase activity (peroxisomes), which was initially reduced in the group with aerobic overgrowth, had doubled following treatment and was then not significantly different comparing these affected with the control animals. In the animals with anaerobic overgrowth, mean specific activities of all these organelle marker enzymes were comparable to those in the control group both before and after treatment.

\section{ANALYTICAL SUBCELLULAR FRACTIONATION}

Figures 1 to 5 show the relative specific activities and density gradient distributions of marker enzymes in jejunal biopsy specimens from control and affected dogs before and after antibiotic therapy. Data before treatment and relevant control data have been presented previously. ${ }^{18}$ Figure 1 shows that treatment of the dogs with aerobic overgrowth was associated with marked recovery of the main brush border component of alkaline phosphatase activity which was severely reduced before treatment; there was now a distinct peak at modal density $1.21 \mathrm{~g} / \mathrm{ml}$ comparable with that in the controls. In contrast, antibiotic therapy had relatively little effect on the distributions of the other brush border marker enzymes. Apart from relatively minor increases in the main brush border components of zinc-resistant $\alpha$-glucosidase (maltase) and aminopeptidase $\mathrm{N}$ activities after antibiotic, distributions both before and after treatment were comparable with those in the control group.

Figure 2 shows that antibiotic therapy had a major effect on the severe brush borders abnormalities in biopsy specimens from animals with anaerobic over- 

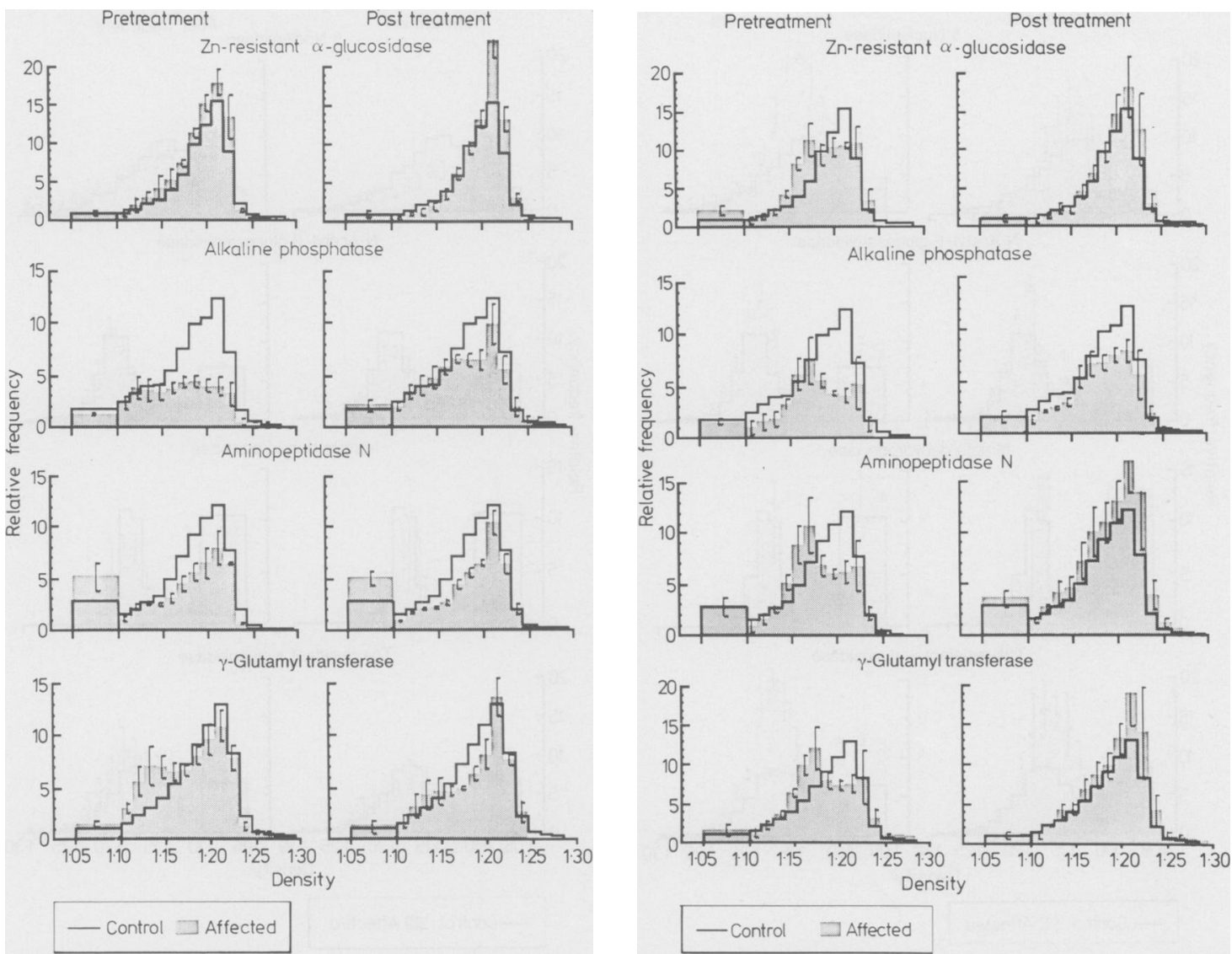

Fig. 1 Distributions of brush border enzymes after subcellular fractionation of jejunal biopsy specimens from control dogs (solid line, $n=8$ ) and affected dogs with aerobic overgrowth (shaded, mean $\pm S E, n=4$ ) before and after antibiotic treatment. For each enzyme the areas comparing these control and affected animals are proportional to enzyme specific activity ( $\mathrm{mU} / \mathrm{mg}$ protein). Density span $1.05-1 \cdot 10$ represents soluble enzyme activity. Mean percentage recoveries for control and affected animals pre-treatment and post-treatment respectively with relative specific activities in parentheses are: zinc-resistant $\alpha$-glucosidase $97,83(1 \cdot 1), 87(1 \cdot 2)$, alkaline phosphatase 75 , $97(0 \cdot 6), 93(0 \cdot 9)$, aminopeptidase $N 92,85(0 \cdot 8), 81(0 \cdot 8)$, $\gamma$-glutamyl transferase, 92, 89(1.0), $95(0 \cdot 9)$.

growth. While the initial distributions of all four enzymes indicated a considerable reduction in brush border density, after antibiotic treatment there was a marked increase in the modal density of each of these enzymes from 1.17 to $1.21 \mathrm{~g} / \mathrm{ml}$, a value now identical to that of the controls.

The distributions of marker enzymes for basolateral membranes ( $5^{\prime}$-nucleotidase) lysosomes $(\mathrm{N}$ acetyl- $\beta$-glucosaminidase), mitochondria (malate

Fig. 2 Distributions of brush border enzymes after subcellular fractionation of jejunal biopsy specimens from control dogs (solid line, $n=8$ ) and affected dogs with anaerobic overgrowth (shaded, mean $\pm S E, n=4$ ) before and after antibiotic treatment. For each enzyme the areas comparing these control and affected animals are proportional to enzyme specific activity ( $\mathrm{mU} / \mathrm{mg}$ protein). Density span 1.05-1.10 represents soluble enzyme activity. Mean percentage recoveries from control and affected animals pre-treatment and post-treatment respectively with relative specific activities in parentheses are: zinc-resistant $\alpha$-glucosidase $97,97(1 \cdot 1), 87(1 \cdot 1)$, alkaline phosphatase 75 , $68(0 \cdot 6), 91(0 \cdot 7)$, aminopeptidase N92, $102(0 \cdot 9), 74(1 \cdot 4)$, $\gamma$-glutamyl transferase, 92, $105(1 \cdot 0), 84(1 \cdot 3)$.

dehydrogenase), and endoplasmic reticulum (Trisresistant $\alpha$-glucosidase) show that densities of these subcellular organelles in biopsy specimens from dogs with aerobic (Fig. 3) and anaerobic overgrowth (Fig. 4) were relatively unaffected by antibiotic treatment. In the latter group (Fig. 4), however, there was some recovery of the particulate mitochondrial component of malate dehydrogenase activity, while the particulate distribution of Tris-resistant $\alpha$-glucosidase was 

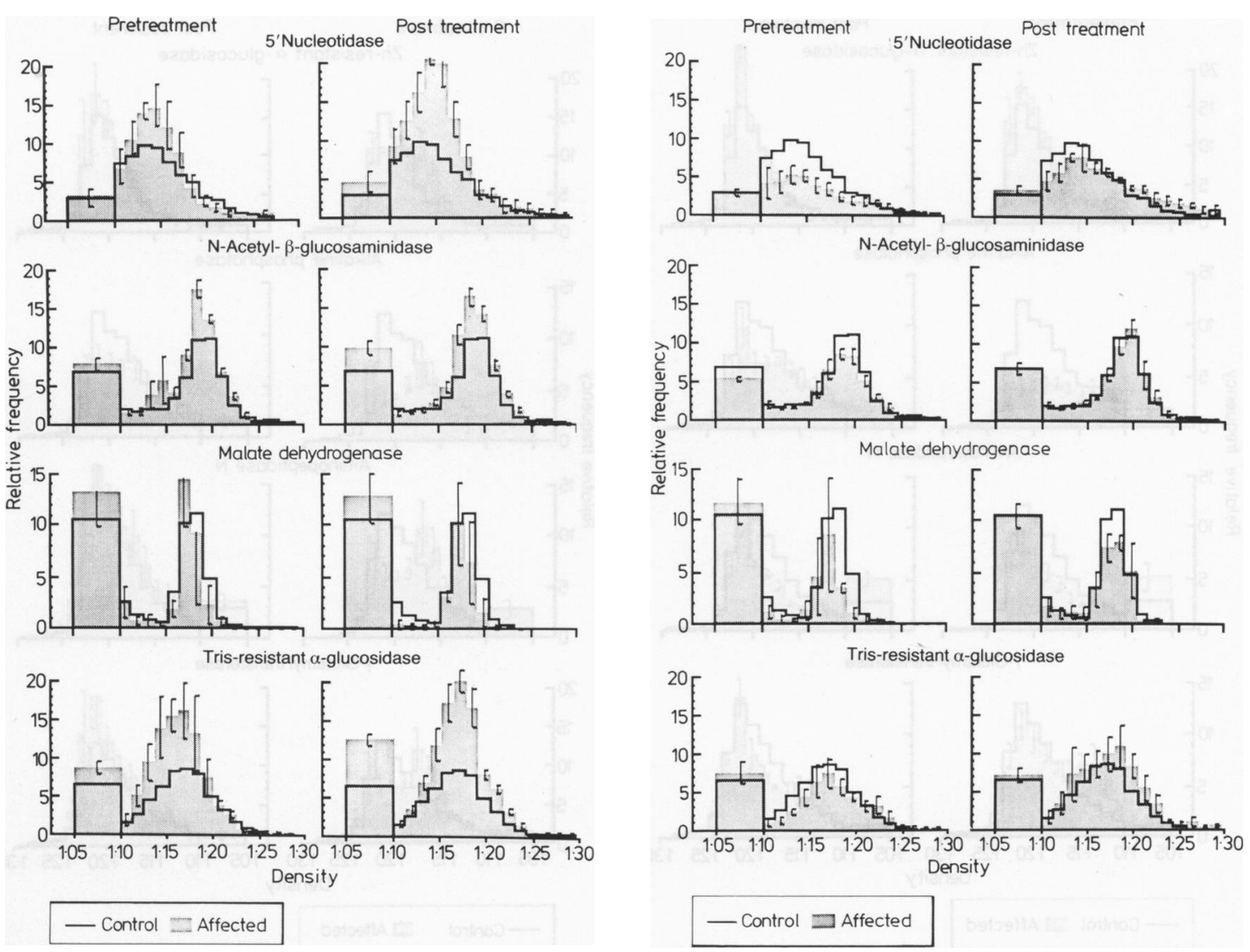

Fig. 3 Distributions of organelle marker enzymes after subcellular fractionation of jejunal biopsy specimens from control dogs (solid line, $n=8$ ) and affected dogs with aerobic overgrowth (shaded, mean $\pm S E n=4$ ) before and after antibiotic treatment. For each enzyme the areas comparing these control and affected animals are proportional to enzyme specific activity ( $\mathrm{mU} / \mathrm{mg}$ protein). Density span $1 \cdot 05-1 \cdot 10$ represents soluble enzyme activity. Mean percentage recoveries for control and affected animals pre-treatment and post-treatment respectively with relative specific activities in parentheses are: $5^{\prime}$-nucleotidase 85,111 $(1 \cdot 2), 112(1 \cdot 7), N$-acetyl-B-glucosaminidase 70, 86 (1.3), 75 $(1 \cdot 4)$, malate dehydrogenase $75,92(1 \cdot 1), 81(0 \cdot 9)$, Trisresistant $\alpha$-glucosidase 109, $89(1 \cdot 7), 93(1 \cdot 9)$.

skewed into the denser fractions. In addition, Figure 5 shows that there was a major change in the distribution of catalase activity in biopsy specimens from the dogs with anaerobic overgrowth, reflecting some decrease in soluble activity and recovery of a particulate peroxisomal peak of modal density $1 \cdot 21$, comparable with that in the controls. Figure 5 also shows that recovery of catalase activity in dogs with aerobic overgrowth represented increases in both

Fig. 4 Distributions of organelle marker enzymes after subcellular fractionation of jejunal biopsy specimens from control dogs (solid line, $n=8$ ) and affected dogs with anaerobic overgrowth (shaded, mean $\pm S E, n=4$ ) before and after antibiotic treatment. For each enzyme the areas comparing these control and affected animals are proportional to enzyme specific activity ( $\mathrm{mU} / \mathrm{mg}$ protein). Density span $1 \cdot 05-1 \cdot 10$ represents soluble enzyme activity. Mean percentage recoveries for control and affected animals pre-treatment and post-treatment respectively with relative specific activities in parentheses are: $5^{\prime}$-nucleotidase 85,83 (0.6), $101(1 \cdot 0), N$-acetyl- $\beta$-glucosaminidase 70, $91(0 \cdot 8), 84$ $(1.0)$, malate dehydrogenase $75,100(0.9), 84(0.9)$, Trisresistant $\alpha$-glucosidase 109, $125(0 \cdot 9), 94(1 \cdot 3)$.

soluble and particulate peroxisomal components of enzyme activity.

\section{Discussion}

Jejunal biopsy specimens taken from dogs with aerobic overgrowth before treatment showed a severe loss of the main brush border component of alkaline phosphatase activity. Subcellular fractiona- 


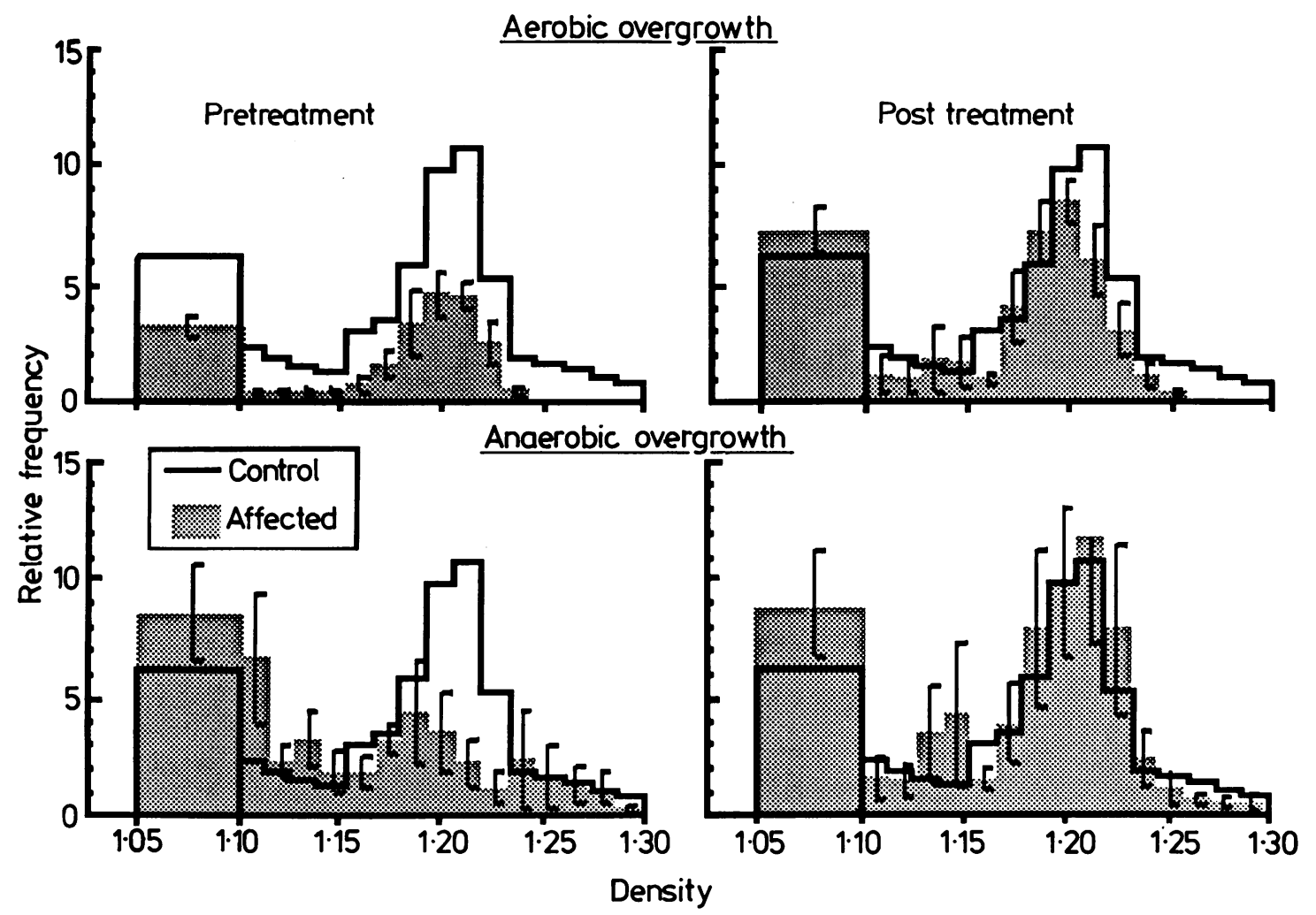

Fig. 5 Distributions of catalase after subcellular fractionation of jejunal biopsy specimens from control dogs (solid line, $n=8$ ) and affected dogs (shaded, mean $\pm S E, n=4$ ) with either aerobic or anaerobic overgrowth before and after antibiotic treatment. For each enzyme the areas comparing these control and affected animals are proportional to enzyme specific activity (mU/mg protein). Density span 1.05-1.10 represents soluble enzyme activity. Mean percentage recoveries for control and affected animals with aerobic or anaerobic overgrowth respectively with relative specific activities in parentheses are: pre-treatment $83,74(0 \cdot 4), 65(0 \cdot 9)$, post-treatment $83,83(0 \cdot 8), 66(1 \cdot 2)$.

tion clearly showed recovery of brush border activity after antibiotic therapy, while there was little effect on the lighter membranous and soluble components of enzyme activity. This indicates that the initial decrease in brush border alkaline phosphatase activity was not an underlying or coincidental abnormality, and supports the suggestion that a loss of alkaline phosphatase reflects a direct effect on the brush border membrane, ${ }^{17}$ by a mechanism involving bacteria, bacterial secretions, or perhaps bacterial metabolites such as deconjugated bile salts and hydroxy fatty acids. ${ }^{2}$ Indeed, it seems unlikely that an indirect consequence of bacterial overgrowth - for example, a specific nutritional deficiency affecting enterocyte maturity, rate of enzyme synthesis or enzyme activity - could have such a specific effect on brush border but not on other subcellular components of alkaline phosphatase activity. Certainly, activities of brush border enzymes do not appear to be reduced by caloric or protein deprivation alone. ${ }^{3031}$ In addition, although malnutrition has been shown to accelerate the development of disaccharidase deficiencies in the experimental blind loop syndrome, this effect is thought not to be indirect but to be mediated by luminal bacteria, perhaps after alteration to the luminal environment or to mucosal defences. ${ }^{12}$

In contrast with findings in the experimental blind loop syndrome, in the present study disaccharidase activities were not affected in the animals with aerobic overgrowth either before or after treatment, emphasising the specificity of the changes in brush border alkaline phosphatase. Because alkaline phosphatase appears to have a strong lipid association ${ }^{32}$ and to be more resistant to release from the membrane than disaccharidases, which are relatively exposed at the membrane surface, ${ }^{33}{ }^{34}$ it seems most likely that the effects on brush border alkaline 
phosphatase activity before and after treatment reflect damage and subsequent recovery of the hydrophobic region of the brush border membrane.

Antibiotic therapy also resulted in considerable improvement in the relatively severe damage to the brush border in the dogs with anaerobic overgrowth. Damage was evidenced by a decrease in modal density, suggestive of a marked fall in the glycoprotein-to-lipid ratio of the brush border membrane. Restoration of normal brush border density after treatment was associated with an alteration in the composition rather than a marked decline in the magnitude of the overgrowth flora, with a notable loss of Clostridia spp. In these dogs, and also in the dogs with aerobic overgrowth, it is possible that total numbers of bacteria might have been more markedly reduced during the treatment period than was evident from the samples obtained after treatment. Some recolonisation might have occurred between last antibiotic administration and resampling, a period intended to minimise interference from any direct effect of oxytetracycline on the mucosa. Nevertheless, a loss of specific obligate anaerobic bacteria, notably Clostridia spp, may be particularly relevant to the recovery of normal brush border density after treatment of the dogs with anaerobic overgrowth. This association is consistent with a normal brush border density in dogs with aerobic overgrowth. ${ }^{18}$ Furthermore, anaerobes have been particularly implicated in the synthesis of glycosidases in the experimental blind loop syndrome, ${ }^{35}$ and in the present study these enzymes could have been responsible for removal of oligosaccharides from surface glycoproteins or glycolipids resulting in the decreased brush border density observed in the dogs with anaerobic overgrowth before treatment.

Study of a larger group of dogs with overgrowth ${ }^{18}$ has indicated that while alkaline phosphatase activity is reduced in animals with aerobic overgrowth this is not a consistent finding in dogs with anaerobic overgrowth. Similarly, alkaline phosphatase activity has been reported to be affected in some ${ }^{y}{ }^{10}$ but not other ${ }^{112}$ studies of animals with anaerobic overgrowth in experimental blind loops. The present study emphasises that although alkaline phosphatase activity may be reduced in individual cases, anaerobic overgrowth can be associated with severe, generalised, and potentially reversible damage to the brush border membrane which would not be detected by coventional biochemical investigations, such as the assay of disaccharidase activities.

Apart from an effect on peroxisomes discussed below, antibiotic treatment resulted in relatively little alteration to the other principal subcellular organelles in either group of dogs with overgrowth. In the dogs with aerobic overgrowth, activity of particulate Tris-resistant $\alpha$-glucosidase remained considerably raised, suggesting that a proliferation of the endoplasmic reticulum might be present before and after treatment. In the dogs with anaerobic overgrowth, Tris-resistant $\alpha$-glucosidase was skewed into the denser particulate fractions after treatment, suggesting some increase in the proportion of rough to smooth endoplasmic reticulum. At present, the importance of these findings is speculative. The former, however, would provide an enhanced capability to synthesise new cellular constituents including protein and membrane lipid, while the latter could reflect a relatively enhanced rate of synthesis of proteins destined for the brush border, as plasma membrane proteins are synthesised and assembled in the rough endoplasmic reticulum..$^{36}$ In addition, a specific increase in particulate malate dehydrogenase activity in the animals with anaerobic overgrowth provided evidence for recovery of the mitochondrial damage implicated by the loss of this activity before treatment.

These changes in endoplasmic reticular and mitochondrial enzymes after treatment were relatively minor compared with the effects on catalase. Indeed, alterations in the activities and density gradient distributions of catalase clearly showed considerable recovery of particulate peroxisomal activities in biopsy specimens from both affected groups. Acting in concert with enzymes such as superoxide dismutase, catalase can play a fundamental role in protection against oxygen free-radicals which might otherwise cause considerable cellular damage - for example, by lipid peroxidation and release of fatty acids from membranes. ${ }^{37}$ In the dogs with aerobic overgrowth, soluble and peroxisomal catalase activities were reduced before treatment, changes that might compromise a local protective role of this enzyme. The significance of this loss of catalase in vivo, however, obviously depends on many factors, particularly on whether this reduced activity is rate limiting in the turnover of the hydrogen peroxide presented. The latter could be produced by many potential substrates of bacterial origin - for example, by the metabolism of ethanol and acetaldehyde, ${ }^{38}$ both of which have been demonstrated in experimental blind loops. ${ }^{39}$ In the animals with anaerobic overgrowth, there was a marked loss of peroxisomal and increase in soluble catalase activity before treatment. While the origin of soluble catalase is unclear ${ }^{41}$ these findings might reflect interference with the transport of catalase into peroxisomes; alternatively they could reflect fragility of the peroxisomal membrane permitting release of catalase from peroxisomes either in vivo or during the homogenisation procedure. A severe loss of particulate catalase activity in vivo could be particularly important 
and could interfere specifically with the ability of peroxisomes to deal with free radicals. The marked improvement after treatment indicates that these abnormalities affecting catalase did not play a primary role in the mucosal damage in dogs with either aerobic or anaerobic overgrowth. A secondary role remains a possibility, but at present the derivation of these abnormalities and their relationship to the pathogenesis of the mucosal changes in these affected animals remain unclear.

This study has shown that major biochemical abnormalities in the jejunal mucosa of dogs with aerobic and anaerobic overgrowth can be largely reversed by antibiotic treatment. The findings indicate that while bacteria can have a major effect on the brush border other subcellular organelles may also be affected, and provide strong evidence that this damage is a direct consequence of the overgrowth.

The authors thank the Wellcome Trust, the BSAVA Clinical Studies Trust Fund, and the German Shepherd Dog League for financial support. We also thank Mr J R Needham, Mrs J Jones, and Dr J R Thomlinson for assistance with the bacteriology.

\section{References}

1 Ament ME, Shimoda SS, Saunders DR, Rubin CE. Pathogenesis of steatorrhea in three cases of small intestinal stasis syndrome. Gastroenterology 1972; 63: 728-47.

2 King CE, Toskes PP. Small intestine bacterial overgrowth. Gastroenterology 1979; 76: 1035-55.

3 Banwell JG, Kistler LA, Giannella RA, Weber FL Jr, Lieber A, Powell DE. Small intestinal bacterial overgrowth syndrome. Gastroenterology 1981; 80: 834-45.

4 Riepe SP, Goldstein J, Alpers DH. Effect of secreted Bacteroides proteases on human intestinal brush border hydrolases. J Clin Invest 1980; 66: 314-22.

5 Gracey M, Burke V, Oshin A, Barker J, Glasgow EF. Bacteria, bile salts, and intestinal monosaccharide malabsorption. Gut 1971; 12: 683-92.

6 Giannella RA, Rout WR, Toskes PP. Jejunal brush border injury and impaired sugar and amino acid uptake in the blind loop syndrome. Gastroenterology 1974; 67: 965-74.

7 Gracey M, Papadimitriou J, Bower G. Ultrastructural changes in the small intestines of rats with self-filling blind loops. Gastroenterology 1974; 67: 646-51.

8 Bloch R, Menge M, Lorenz-Meyer H, Stöckert HG, Riecken EO. Functional, biochemical and morphological alterations in the intestines of rats with an experimental blind loop syndrome. Res Exp Med 1975; 166: 67-8.

9 Gracey M, Thomas J, Houghton M. Effect of stasis on intestinal enzyme activities. Aust NZ J Med 1975; 5: 141-4.

10 Toskes PP, Giannella RA, Jervis HR, Rout WR,
Takeuchi A. Small intestinal mucosal injury in the blind loop syndrome: light and electron-microscopic and histochemical studies. Gastroenterology 1975; 68: 1193-203.

11 Jonas A, Flanagan PR, Forstner GG. Pathogenesis of mucosal injury in the blind loop syndrome. Brush border enzyme activity and glycoprotein degradation. J Clin Invest 1977; 60: 1321-30.

12 Sherman P, Wesley A, Forstner G. Sequential disaccharidase loss in rat intestinal blind loops: impact of malnutrition. Am J Physiol 1985; 248: G626-32.

13 Jonas A, Krishnan C, Forstner G. Pathogenesis of mucosal injury in the blind loop syndrome. Release of disaccharidases from brush border membranes by extracts of bacteria obtained from intestinal blind loops in rats. Gastroenterology 1978; 75: 791-5.

14 Gorbach SL, Banwell JG, Jacobs B, et al. Tropical sprue and malnutrition in West Bengal. 1. Intestinal microflora and absorption. Am J Clin Nutr 1970; 23: 1545-58.

15 Gorbach SL. Intestinal microflora. Gastroenterology 1971; 60: 1110-29.

16 Klipstein FA, Holdeman LV, Corcini JJ, Moore WEC. Enterotoxigenic intestinal bacteria in tropical sprue. Ann Intern Med 1973; 79: 632-41.

17 Batt RM, Carter MW, Peters TJ. Biochemical changes in the jejunal mucosa of dogs with a naturally occurring enteropathy associated with bacterial overgrowth. Gut 1984; 25: 816-23.

18 Batt RM, McLean L. Comparison of the biochemical changes in the jejunal mucosa of dogs with aerobic and anaerobic bacterial overgrowth. Gastroenterology 1987; 93: 986-93.

19 Batt RM, Mann LC. The specificity of the BT-PABA test for the diagnosis of exocrine pancreatic insufficiency in the dog. Vet Rec 1981; 108: 303-7.

20 Batt RM, Morgan JO. Role of serum folate and vitamin $B_{12}$ concentrations in the differentiation of small intestinal abnormalities in the dog. Res Vet Sci 1982; 32: $17-22$.

21 Williams DW, Batt RM. Diagnosis of canine exocrine pancreatic insufficiency by the assay of serum trypsinlike immunoreactivity. J Small Anim Pract 1983; 24: 583-8.

22 Batt RM, Needham JR, Carter MW. Bacterial overgrowth associated with a naturally occurring enteropathy in the German shepherd dog. Res Vet Sci 1983; 35: 42-6.

23 Batt RM. Techniques for single and multiple peroral jejunal biopsy in the dog. J Small Anim Pract 1979; 20: 259-68.

24 Batt RM, Peters TJ. Subcellular fractionation studies on peroral jejunal biopsies from the dog. Res Vet Sci 1978; 25: $94-100$.

25 Batt RM, McLean L, Carter MW. Sequential morphologic and biochemical studies of a naturally occurring wheat-sensitive enteropathy in Irish setter dogs. Dig Dis Sci 1987; 32: 184-94.

26 Leighton $\mathrm{F}$, Poole $\mathrm{B}$, Beaufay $\mathrm{H}$, et al. The large scale separation of peroxisomes, mitochondria and lysosomes from the liver of rats injected with Triton WR 1339. J Cell Biol 1968; 37: 482-513.

27 Batt RM, Bush BM, Peters TJ. Biochemical changes in 
the jejunal mucosa of dogs with naturally occurring exocrine pancreatic insufficiency. Gut 1979; 20: 709-15.

28 Peters TJ, Batt RM, Heath JR, Tilleray J. The microassay of intestinal disaccharidases. Biochem Med 1976; 15: $145-8$

29 Schacterle GR, Pollack RL. A simplified method for the quantitative assay of small amounts of protein in biologic material. Anal Biochem 1974; 51: 654-5.

30 Solimano G, Burgess EA, Levin B. Protein-calorie nutrition: effect of deficient diets on enzyme levels of jejunal mucosa of rats. Br J Nutr 1967; 2: 55-66.

31 Troglia OM, Laughrey EG, Henley KS. Effect of quantitative undernutrition on the activities of intestinal disaccharidases in the rat. Gastroenterology 1970; 58: 669-72.

32 Nayudu PRV, Hercus FB. Molecular heterogeneity of mouse duodenal alkaline phosphatase. Biochem J 1974; 141: $93-101$.

33 Louvard D, Maroux S, Vannier Ch, Desnuelle P. Topological studies on the hydrolases bound to the intestinal brush border membrane. 1. Solubilization by papain and Triton X-100. Biochim Biophys Acta 1975; 375: $236-48$.

34 Colbeau A, Maroux S. Integration of alkaline phos- phatase into the intestinal brush border membrane. Biochim Biophys Acta 1978; 511: 39-51.

35 Prizont R. Glycoprotein degradation in the blind loop syndrome. Identification of glycosidases in jejunal contents. J Clin Invest 1981; 67: 336-44.

36 Sabatini DD, Kreibich G, Morimoto T, Adesnik M. Mechanisms for the incorporation of proteins in membranes and organelles. J Cell Biol 1982; 92: 1-22.

37 Hansson R, Johansson S, Jonsson O, Pettersson S, Scherstén $T$, Waldenström $J$. Kidney protection by pretreatment with free radical scavengers and allopurinol: renal function at recirculation after warm ischaemia in rabbits. Clin Sci 1986; 71: 245-51.

38 Cederbaum AI, Dicker E, Rubin E, Cohen G. The effect of dimethylsulphoxide and other hydroxyl radical scavengers on the oxidation of ethanol by rat liver microsomes. Biochem Biophys Res Commun 1977; 78: 1254-62.

39 Baraona E, Julkunen R, Tannenbaum L, Lieber CS. Role of intestinal bacterial overgrowth in ethanol production and metabolism in rats. Gastroenterology 1986; 90: 103-10.

40 Tolbert NE, Essner E. Microbodies: peroxisomes and glyoxysomes. J Cell Biol 1981; 91: 271s-83s. 